University of Rhode Island

DigitalCommons@URI

The Rhode Island Current Conditions Index

Economics

$10-2013$

\title{
Rhode Island Current Conditions Index - October 2013
}

Leonard Lardaro

University of Rhode Island, lardaro@uri.edu

Follow this and additional works at: https://digitalcommons.uri.edu/ricci

Part of the Econometrics Commons

Terms of Use

All rights reserved under copyright.

\section{Recommended Citation}

Lardaro, Leonard, "Rhode Island Current Conditions Index -- October 2013" (2013). The Rhode Island Current Conditions Index. Paper 92.

https://digitalcommons.uri.edu/ricci/92

This Article is brought to you for free and open access by the Economics at DigitalCommons@URI. It has been accepted for inclusion in The Rhode Island Current Conditions Index by an authorized administrator of DigitalCommons@URI.For more information, please contact digitalcommons-group@uri.edu. 


\section{CURRENT CONDITIONS}

LEONARD LARDARO, URI

\section{Available Online: http:/ / www.Ilardaro.com/ current.htm (NEW URL) Blog: http:/ / rieconomy.blogspot.com}

VOL XX

NUMBER 11 OCT 2013
Rhode Island began the fourth quarter by continuing its positive, though not exactly stunning, momentum. Once again, there was both good news and bad news concerning Rhode Island's economic performance. First, the good news: the Current Conditions Index rose from 67 (revised down) in September to 75 in October, as nine of its twelve indicators improved. Importantly, several of those improvements were quite stunning. The bad good news emerges when we contrast our state's performance this year with that in 2012: for a third consecutive month, and the fourth time in five months, the $\mathrm{CCl}$ has failed to exceed its year-earlier value. I strongly suspect that this will be the dominant pattern throughout the fourth quarter. If this conjecture proves correct, which I believe it will, we will experience a slowing in our rate of growth relative to the end of last year. One could argue that the late-2012 acceleration confronts us this year with a difficult "comp," which is true. However, as our state's current rate of growth is not terribly rapid (Rhode Island's growth rate in rea state GDP for 2012 was only $1.4 \%$ ), the test of how robust this recovery will ultimately prove to be will be defined by our ability to accelerate rather than sustain growth rates comparable to what we observed at the end of 2012. Fortunately, the US economy is growing more rapidly, which will clearly benefit Rhode Island.

One hint of future momentum can be inferred from the October performance of the leading indicators contained in the $\mathrm{CCl}$. For October, four of the five leading indicators improved in spite of difficult "comps" from a year ago. The only leading indicator that failed to improve, US Consumer Sentiment, fell sharply $(-11 \%)$, but this was heavily influenced by a one-two punch: the

\begin{tabular}{|l|r|r|}
\hline \multicolumn{2}{|c|}{ CCI Indicators - \% Change } \\
\hline Government Employment & -0.5 \\
\hline US Consumer Sentiment & -11.0 & \\
\hline Single-Unit Permits & $\mathbf{6 1 . 3}$ & $\mathrm{Y}$ \\
\hline Retail Sales & $\mathbf{0 . 0}$ & $\mathrm{Y}$ \\
\hline Employment Services Jobs & $\mathbf{4 . 2}$ & $\mathrm{Y}$ \\
\hline Priv. Serv-Prod Employment & $\mathbf{1 . 4}$ & $\mathrm{Y}$ \\
\hline Total Manufacturing Hours & $\mathbf{2 . 4}$ & $\mathrm{Y}$ \\
\hline Manufacturing Wage & 3.0 & $\mathrm{Y}$ \\
\hline Labor Force & -2.1 & \\
\hline Benefit Exhaustions & -35.3 & $\mathrm{Y}$ \\
\hline New Claims & $-\mathbf{8 . 9}$ & $\mathrm{Y}$ \\
\hline Unemployment Rate (change) & $-\mathbf{0 . 9}$ & $\mathrm{Y}$ \\
\hline \multicolumn{2}{|c|}{ Y Improved Value } \\
\hline
\end{tabular}

combination of the government shutdown and its rise of over 37 percent last October. While October was the second consecutive decline for Sentiment, it remains in a well-defined uptrend that will likely continue as long as the stock market continues to rise.

So, while our state's economic momentum appears to be slowing a bit, substantial momentum remains, based on the performances of both the leading indicators contained in the $\mathrm{CCl}$ and several of its non-leading indicators. Sadly, this means it will take longer for us to return to our prior peak in economic activity. Welcome to our world! Our elected officials have yet to fully grasp that success in a post-manufacturing economy requires consistent and persistent effort to make improvements to a state's economy, not merely waiting for things to "turn around."

All of the remaining leading indicators improved in October. The uptrend in Single-Unit Permits, a leading indicator of housing, continued with a vengeance, rising 61.3 percent relative to last October. Clearly, Rhode Island's housing sector is continuing to move well beyond its recession trough. Employment Service Jobs, which includes temporary employment, a prerequisite to overall employment growth, rose by a healthy 4.2 percent in October. It has declined only once in over a year and it remains in a clear uptrend. New Claims for Unemployment Insurance, the most timely measure of layoffs, improved in October, falling by 8.9 percent in spite of a very large decline last year $(-9.8 \%)$. Unlike the leading indicators discussed earlier, this indicator is not in a well-defined downtrend at present. Should it begin to rise, it would threaten our state's future momentum, since a trend of rising layoffs would adversely affect other $\mathrm{CCl}$ indicators in coming months, most notably Retail Sales. The final leading indicator, Total Manufacturing Hours, which measures strength in our manufacturing sector, rose by 2.4 percent in October. This indicator has improved for ten of the last twelve months, something I never thought I would see again, especially as one of the foundations of our recovery's momentum.

Retail Sales was flat, growing by only 0.003 percent relative to last October. Private Senvice-Producing Employment growth finally moved above one percent $(+1.4 \%)$, our state's Labor Force declined yet again (the seventh consecutive time), and in spite of this, our Unemployment Rate was flat over the month. Finally, Government Employment edged down a bit.
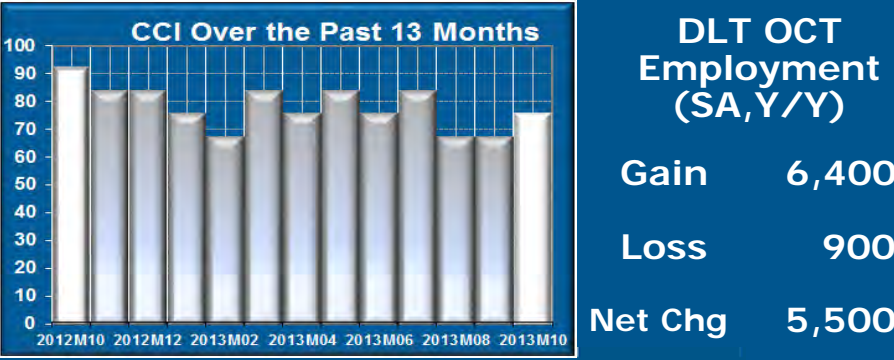

\section{THE BOTTOM LINE}

As the fourth quarter begins, Rhode Island's economy is at a turning point of sorts: an inflection point in terms of overall momentum relative to late 2012. The $\mathrm{CCl}$ has now failed to exceed its year-earlier value for three consecutive months, a pattern I expect to recur for the remainder of 2013. Slower growth doesn't necessarily mean the floor is about to cave in (strange hearing that coming from me!), since a fair amount of momentum remains and it should benefit from the accelerating pace of national activity. If, and when, our elected officials institute meaningful changes we will be able to avoid inflection-based realities such as what we now face. The key word is "if."

\begin{tabular}{|c|c|c|c|c|c|c|c|c|c|c|c|c|c|}
\hline & & Jan & Feb & Mar & Apr & May & $J$ un & $\mathrm{Jul}$ & Aug & Sep & Oct & Nov & Dec \\
\hline & 2012 & $67 \uparrow$ & $58 \uparrow$ & 58 & $67 \uparrow$ & $67 \uparrow$ & $83 \uparrow$ & $58 \uparrow$ & $92 \uparrow$ & $75 \uparrow$ & $92 \uparrow$ & $83 \uparrow$ & $83 \downarrow$ \\
\hline & 2013 & 75 & 67 & 83 & $75 \uparrow$ & 83 & 75 & $83 \uparrow$ & 67 & $67 \downarrow$ & 75 & & \\
\hline
\end{tabular}

